\title{
How to Deserve
}

\author{
David Schmidtz*
}

Philosophy Department, University of Arizona, Tucson, AZ 85721

\begin{abstract}
It is at very least a prominent view among political philosophers that common sense is mistaken in its optimism about the possibility of our being deserving. One reason is ideological: many high-profile academic conceptions of distributive justice are incompatible with common-sense thinking about what we deserve. Another reason is that it is, after all, startlingly difficult to come up with a philosophical framework that grounds significant claims about what individuals deserve. We are born, we are raised, we are given opportunities, and we are made into beings who can to some extent take advantage of opportunities. At least from a mechanistic world-view, it is hard to see any room in that picture for being deserving of what we accomplish with our opportunities. This essay makes room. It distinguishes between the compensatory model of desert in which one can deserve something only on the basis of what one did before receiving it, and a promissory model in which one can deserve a chance in virtue of what one will do to deserve it.
\end{abstract}

People ought to get what they deserve. And what we deserve can depend on effort, on performance, or on excelling in competition, even when excellence is partly a function of our natural gifts. Or so most people believe. Philosophers sometimes say otherwise. At least since Karl Marx complained about capitalist society extracting surplus value from workers, thereby failing to give workers what they deserve, classical liberal philosophers have worried that to treat justice as a matter of what people deserve is to license interference with liberty.

\section{INTRODUCTION}

Rawls likewise rejected patterns imposed by principles of desert, saying that no one deserves his place in the distribution of natural endowments, any more than one deserves one's initial starting place in society. The assertion that a man deserves the superior character that enables him to make the effort to cultivate his abilities is equally problematic; for his character depends in large part upon fortunate family and social circumstances for which he can claim no credit. The notion of desert seems not to apply to these cases. ${ }^{1}$

Rawls's view is, in a way, compelling. Inevitably, our efforts are aided by natural gifts, positional advantages, and sheer luck, so how much can we deserve? And if our very characters result from an interplay of these same factors, how can we (capitalists and workers alike) deserve anything at all?

*Address correspondence to this author at the Philosophy Department, University of Arizona, Tucson, AZ 85721; USA;

E-mail: schmidtz@email.arizona.edu

\footnotetext{
\# Kendrick Professor of Philosophy, University of Arizona.

This essay is a reprinting (with some revisions) David Schmidtz, "How to Deserve," Political Theory 30 (2002): 774-99. Reprinted here by kind permission of Sage Publications. All rights reserved.

${ }^{1}$ Rawls (1971) 104. Rakowski $(1991,112)$ sees the passage as an "uncontroversial assertion, which even libertarians such as Nozick accept." Scheffler $(1992,307)$ likewise calls the passage "uncontroversial." Hayek $(1960,94)$ says, "A good mind or a fine voice, a beautiful face or a skilful hand, and a ready wit or an attractive personality are in large measure as independent of a person's efforts as the opportunities or experiences he has had." Hayek insists it is neither desirable nor practicable to ask basic structure to distribute according to desert. Gauthier $(1986,220)$ says, "We may agree with Rawls that no one deserves her natural capacities. Being the person one is, is not a matter of desert," although Gauthier doubts that this fact has normative implications.
}

Does Rawls leave no room for desert? Rawls's intent may have been narrower: simply to eliminate a rival to his difference principle as a test of the justness of basic structure. Whatever he intended, though, his critique of desert has no such surgical precision. We know Rawls intended his two principles to apply only to society's basic structure, but his critique of desert is not similarly constrained, and cannot be constrained merely by stipulating or intending that it be so constrained. When Rawls says "the concept of desert seems not to apply" to cases where outcomes are influenced by natural advantages or by character, he is implicating the larger moral universe, not merely basic structure. In particular, he wants to say the larger moral universe contains nothing (beyond his own first principle) to stop his difference principle from being the test of basic structure's justness. If Rawls's attack on desert is warranted, then the skepticism he is justifying is of a global nature. $^{2}$

Scheffler says "none of the most prominent contemporary versions of philosophical liberalism assigns a significant role to desert at the level of fundamental principle." 3 If so, I argue, then these prominent contemporary versions of philosophical liberalism are mistaken. In particular, there is an aspect of what we do to make ourselves deserving that, although not discussed in the literature, plays a central role in everyday moral life, and for good reason.

\section{THE "BIG BANG" THEORY}

Nearly everyone would say people ought to get what they deserve. But if we ask what people deserve, or on what basis,

\footnotetext{
${ }^{2}$ Rawls sometimes says he is arguing not against desert per se but only against desert as a preinstitutional notion. I will return to this issue.

${ }^{3}$ Scheffler (1992) 301.
} 
people begin to disagree. A few will say we deserve things simply in virtue of being human, or being in need. Many will say we deserve reward for our efforts, or for the real value our efforts create. It is not necessary, and may not even be feasible, to produce a complete catalog of all possible desertbases. Suffice it to say that the standard bases on which persons commonly are said to be deserving include character, effort, and achievement. ${ }^{4}$

What are we doing when we deem someone deserving, that is, when we acknowledge someone's character, effort, or achievement? Here is a suggestion: to judge Bob deserving is to judge Bob worthy. It is to judge that Bob has features that make a given outcome Bob's just reward. ${ }^{5}$ Intuitively, although less obviously, to acknowledge that there are things Bob can do to be deserving is to acknowledge that Bob is a person: able to choose and to be responsible for his choices. ${ }^{6}$ Something like this is implicit in normal deliberation about what a person deserves.

The skeptics' theory, in its most sweeping form, depicts desert in such a way that to deserve $\mathrm{X}$, we not only must supply inputs standardly thought to ground a desert claim but also must be deserving of everything about the world, including its history, that put us in a position to supply that input. In effect, the possibility of our being deserving ended with the big bang.

Recall Rawls's claim that a man's “character depends in large part upon fortunate family and social circumstances for which he can claim no credit."7 Rawls repeatedly stressed, and thus evidently thought it relevant, that "even the willingness to make an effort, to try, and so to be deserving in the ordinary sense is itself dependent upon happy family and social circumstances." 8 Needless to say, we all have whatever we have partly in virtue of luck, and luck is not a desert maker. Every outcome is influenced by factors that are morally arbitrary. ('Arbitrary' has a negative connotation, but without further argument, we are entitled only to say luck is morally neutral or inert. That is how I use the term here.) However, does the supposition that some of an outcome's causal inputs are arbitrary entail that all of them must be?

Of course not. Everyone is lucky to some degree, but the more a person supplies in terms of effort or excellence, the less weight we put on the inevitable element of luck. In any case, there is a big difference between being lucky and being merely lucky. The bare fact of being lucky is not what precludes being deserving. Being merely lucky is what precludes being deserving, because to say we are merely lucky is to say we have not supplied inputs (the effort, the excellence) that ground desert claims.

To rebut a desert claim in a given case, we must show that inputs that can ground desert claims are missing in that case. On a nonvacuous conception of desert, there will be inputs that a person can supply, and therefore can fail to

\footnotetext{
${ }^{4}$ Feinberg $(1970,58)$ coins the term 'desert base' to refer to what grounds desert claims. The idea is that well-formed desert claims are three-place relations of the form "P deserves $\mathrm{X}$ in virtue of feature F."

${ }^{5}$ See Sher (1987) 195. See also Narveson (1995) 50-51.

${ }^{6}$ See Morris (1991)

${ }^{7}$ Rawls (1971) 104

${ }^{8}$ Rawls (1971) 74.
}

supply. In general, finding that $\mathrm{X}$ falls outside a category is interesting only if falling inside is a real possibility. ${ }^{9}$

A further point; there are infinitely many inputs that do not ground desert claims (luck, the big bang). So what? Skeptics say every causal chain has morally arbitrary links, but no one doubts that. The truly skeptical idea is that no chain has nonarbitrary links. A skeptic says, "Even character, talent, and other internal features that constitute us as persons are arbitrary so long as they are products of chains of events containing arbitrary links. Every causal chain traces back to something arbitrary, namely the Big Bang. Therefore, nothing is deserved." 10

Some causal chains work their way through features internal to persons; it would be strangely credulous for a skeptic unquestioningly to assume this does not matter. If a so-called skeptic says, "Character is arbitrary," then someone who is properly skeptical replies, "Compared to what?" We distinguish outcomes that owe something to a person's character from outcomes that do not. Desert makers, if there are any, are relations between outcomes and internal features of persons. We need not (and normally do not) assume anything about what caused those features.

Is it odd that we normally make no assumptions about a desert maker's causal history? What if we had been talking about features of nonpersons? Joel Feinberg observes: "Art objects deserve admiration; problems deserve careful consideration; bills of legislation deserve to be passed."11 John Kleinig says the Grand Canyon deserves its reputation. ${ }^{12}$ Such remarks are offered as small digressions, noted and then set aside, but they point to something crucial. We never say the Grand Canyon deserves its reputation only if it in turn deserves the natural endowments on which its reputation is based. We never question artistic judgments by saying, "Even the greatest of paintings were caused to have the features we admire. Not one painting ever did anything to deserve being caused to have those features." Intuitively, obviously, it doesn't matter.

Skeptics assume it does matter in the case of persons, but the assumption is groundless. To my knowledge, it has never been defended. As with nonpersons, when a person's internal features support desert claims, the support comes from appreciating what those features are, not from evidence that they are uncaused.

Some will say desert claims about paintings do not mean the same thing as desert claims about persons. Not so. The meaning is the same; what changes are the stakes. We do not need to reject claims about what paintings deserve to make room for our favorite principle of distributive justice; we need only reject claims about what persons deserve. This

\footnotetext{
${ }^{9}$ We entertained the idea that character is an accident of nature/nurture for which we deserve no credit. In some way, that must be true, but where does it end? Could I have had an altogether different character, or is there a point beyond which such a person would not have been me? Am I lucky I was born human when I could have been a seagull? (Is there a seagull out there that could have been me?) Would we be wrong to say luck is a matter of what happens to me, whereas my basic nature (the fact that I have my character rather than yours) did not happen to me-it $i s$ me?

${ }^{10}$ See Brock's (1999) discussion in a subsection entitled "How can we deserve anything since we don't deserve our asset bases?" Those who reject the premise (that, to be a desert maker, an input must itself be deserved in turn) include Narveson (1995, $67)$, Sher $(1987,24)$, and Zaitchik $(1977,373)$.

${ }^{11}$ Feinberg (1970) 55.

${ }^{12}$ Kleinig (1971).
} 
difference in what is at stake is why big bang theories are deployed only against desert claims made on behalf of persons. Stakes aside, though, big bang theories are as undefended for persons as for paintings.

Here, then, is where matters currently stand. Ordinary thought about desert would be a recipe for skepticism if it were true that ordinary practice presupposes that people deserve credit for doing $\mathrm{X}$ only when people in turn deserve credit for having the ability and opportunity to do $\mathrm{X}$. However, because ordinary practice assumes no such thing, ordinary practice has no such problem. We are left with two options. First, we can say no one deserves anything, and that is what we will say if we assume we deserve credit for working hard only if we in turn deserve credit for being "destined" to work hard. The second option is to say we deserve credit for working hard not because we deserve to have been destined to work hard but simply because we did, after all, work hard. The latter is our ordinary practice.

Neither option is compelling. We are not forced to believe in desert; neither are we forced to be skeptics. We decide. We can ask whether we treat people more respectfully when we give them credit for what they do or when we deny them credit. Or we can ask what kind of life we have when we live by one conception rather than another. These are different questions, and not the only ones we could ask. Perhaps the answers all point in the same direction. Perhaps not. Sweeping skepticism is unattractive to most people, but there is no denying that skepticism is an option, and that some do choose to be skeptics. ${ }^{13}$

Refuting skeptics and answering "How can we deserve anything at all?" are different tasks. We can answer the question, but not by refuting skeptics. For those who want an answer-who want an alternative to skepticism-my objective is to make room within a philosophically respectable theory of justice for the idea that there are things we can do to be deserving.

So, when we consider how much sheer good luck we needed to get where we are today, it is natural for us to wonder, "Do I deserve this?" What does the question mean? If we translate the question as, "What did I do, at the moment of the Big Bang, to deserve this?" the answer is, "Nothing. So what?" If we translate the question as "What did I do, before being born, to deserve this?" the answer again is "Nothing. So what?" However, if we translate the question as "What did I do to deserve this?" then the question will have a real answer.

Also eminently sensible would be to ask, "What can I do to deserve this?" This question, too, will have an answer. The answer may be that, as it happens, there is nothing I can do, but that is not preordained. A theory that lets us ask and answer this question is a theory that lets the concept of desert be what it needs to be in human affairs: a message of hope

\footnotetext{
${ }^{13}$ Walzer $(1983,260)$ says, "Advocates of equality have often felt compelled to deny the reality of desert." In a footnote, Walzer says he means Rawls. Walzer sees Rawls's argument as supposing "the capacity to make an effort or to endure pain is, like all their other capacities, only the arbitrary gift of nature or nurture. But this is an odd argument, for while its purpose is to leave us with persons of equal entitlement, it is hard to see that it leaves us with persons at all. How are we to conceive of these men and women once we have come to view their capacities and achievements as accidental accessories, like hats and coats they just happen to be wearing? How, indeed, are they to conceive of themselves?"
}

that is at the same time life's greatest moral challenge. Such a theory acknowledges the existence of persons: beings who make choices and who are accountable for the choices they make.

In summary, a genuine theory of desert tells us what to look for when investigating what particular people have done. A genuine theory will not say what "big bang" theories say: namely, we need not investigate actual histories of particular people, since we know a priori as a perfectly general feature of human nature that no one deserves anything.

\section{DESERVING A CHANCE}

Suppose we know what a person has to do to be deserving. Is there also a question about when a person has to do it? James Rachels says "what people deserve always depends on what they have done in the past." ${ }^{14}$ David Miller says "desert judgments are justified on the basis of past and present facts about individuals, never on the basis of states of affairs to be created in the future." 15 Joel Feinberg says "if a person is deserving of some sort of treatment, he must, necessarily, be so in virtue of some possessed characteristic or prior activity." 16

If we are not careful, we could interpret such statements in a way that would overlook an important, perhaps the most important, kind of desert-making relation. It is conventional that what we deserve depends on what we do, and that we deserve no credit for what we do until we do it. I now believe that there is a further academic gloss on this convention, though, namely that when we first receive (for example) our natural and positional advantages, if we have not already done something to deserve them, it is too late. We are born into our advantages by mere luck, and that which comes to us by mere luck can never be deserved.

This more specific academic gloss is what I reject. I said being merely lucky precludes being deserving. I did not say, and do not believe, that being merely lucky at $t_{1}$ precludes being deserving at $t_{2}$. In particular, we do not deserve our natural gifts at the moment of our birth, but that need not matter. What matters, if anything at all matters, is what we do after the fact. ${ }^{17}$ Let me make a claim that may at first seem counterintuitive:

We sometimes deserve $\mathrm{X}$ on the basis of what we do after receiving $\mathrm{X}$.

Upon receiving a surprisingly good job offer, a new employee vows to work hard to deserve it. No one ever thinks the vow is paradoxical. No one takes the employee aside and says, "Relax. There's nothing you can do. Only the past is relevant." But unless such everyday vows are misguided, we can deserve $\mathrm{X}$ on the basis of what we do after receiving $\mathrm{X}$.

How can this be? Isn't it a brute fact that when we ask whether a person deserves $\mathrm{X}$, we look backward, not

\footnotetext{
${ }^{14}$ Rachels (1997) 176.

${ }^{15}$ Miller (1976) 93.

${ }^{16}$ Feinberg (1970) 48. Emphasis added.

${ }^{17}$ In passing, there are desert bases that do not require action, such as when we say the Grand Canyon deserves its reputation. It deserves its reputation because of what it is, not because of what it did. I thank Neera Badhwar for noting the implication: being merely lucky only sometimes precludes being deserving.
} 
forward? If we concede for argument's sake that we look back, we would still need to ask: back from where? Perhaps we look back from where we are, yet mistakenly assume we look back from where the recipient was at the moment of receiving $X$. If we look back, a year after hiring Jane, wondering whether she deserved the chance, what do we ask? We ask what she did with it. When we do that, we are looking back even while looking at what happened after she received $X$. From that perspective, we see we can be deserving of opportunities. ${ }^{18} \mathrm{We}$ deserve them by not wasting them-by giving them their due, as it were. ${ }^{19}$

Therefore, even if we necessarily deserve no credit for what we do until after we do it, it does not follow-and indeed is not true-that if we have not already done something to deserve an opportunity by the moment we receive it, then it is too late. Imagine another case. Two students receive scholarships. One works hard and gets excellent grades. The other parties her way through her first year before finally being expelled for cheating. Does their conduct tell us nothing about which of them was more deserving of a scholarship?

Can we save the convention (that whether we deserve $\mathrm{X}$ depends entirely on what happens before we receive $X$ ) by saying the students' conduct is relevant only because it reveals what they were like before the award? No. When we look back at the expelled student's disgraceful year, our reason for saying she did not deserve her award has nothing to do with speculation about what she did in high school. Both students may have been qualified for scholarships qua reward. Or equally unqualified: suppose both were chosen via clerical error, and before that were equally destined for a lifetime of failure. The difference we care about here, and have reason to care about, concerns the subsequent performance, not the prior qualification. What grounds our conviction that one is more worthy of the scholarship qua opportunity is that one student gave the opportunity its due; the other did not. Again:

We sometimes deserve $\mathrm{X}$ on the basis of what we do after receiving $\mathrm{X}$.

Needless to say, skeptics greet this conclusion with skepticism. Why? Part of the answer is that we learn as philosophers to focus on desert as a compensatory notion. The idea is, desert makers we supply before getting $\mathrm{X}$ put a moral scale out of balance, and our getting $X$ rebalances the scale. To those who see desert as necessarily a compensatory notion, we deserve $\mathrm{X}$ only if $\mathrm{X}$ represents a restoring of moral balance. We deserve $X$ only if we deserve it qua reward-only if our receiving $X$ settles an account.

\footnotetext{
${ }^{18}$ I speak interchangeably of deserving a chance, being deserving of a chance, and being worthy of it. Sometimes, it is more natural to describe a person as being deserving of $\mathrm{X}$ rather than as deserving $\mathrm{X}$, especially when the question concerns opportunity rather than reward. But this is a verbal point. If a student said "No one deserves anything, yet there is much of which people are deserving," we would think the student was making an obscure joke.

${ }^{19}$ Is this a sufficient condition? No. If something is wrong with the opportunity, as when we have a chance to use stolen property, then not wasting the opportunity does not suffice to show we deserve it. We could say the same of standard theories about deserving rewards: when we know the reward is stolen property, qualifying for it does not suffice to show we deserve it. In the same way, we may think we establish title to a previously unowned good by mixing our labor with it, without thinking that labormixing can give us title to what otherwise is someone else's property.
}

In ordinary use, though, desert sometimes is a promissory notion. Sometimes our receiving $\mathrm{X}$ is what puts the moral scale out of balance, and our subsequently proving ourselves worthy of $\mathrm{X}$ is what restores it. $\mathrm{X}$ need not be compensation for already having supplied the requisite desert makers. Sometimes it is the other way around. There are times when supplying desert makers is what settles the account.

In either case, two things happen, and the second settles the account. In compensatory cases, desert-making inputs are supplied first; responding with rewards settles the account. In promissory cases, opportunities are supplied first; responding with desert-making inputs settles the account. In promissory cases, a new employee who vows "I will do justice to this opportunity. I will show you I deserve it" is not saying future events will retroactively cause her receiving $X$ to count as settling an account now. Instead, she is saying future events will settle the account. She claims not that she is getting what she already paid for but that she is getting what she will pay for. ${ }^{20}$

So why does James Rachels assert that "what people deserve always depends on what they have done in the past"? ${ }^{21}$ Rachels says, "the explanation of why past actions are the only bases of desert connects with the fact that if people were never responsible for their own conduct-if strict determinism were true-no one would ever deserve anything." 22 Crucially, when he says, "past actions are the only bases of desert," Rachels is stressing "actions," not "past." What Rachels sees as the unacceptable alternative is not a theory like mine, but rather the view that people deserve to be rewarded for having natural endowments. He is thinking of past actions versus past nonactions, and is not considering whether actions postdating $X$ 's receipt might be relevant. That is why Rachels could see himself as explaining why "past actions are the only bases of desert" when he says, "if people were never responsible for their own conduct . . . no one would ever deserve anything." Notice that this argument in no way connects desert bases to events predating X's receipt. The argument connects desert to action, but not particularly to past action. ${ }^{23}$

Rachels also says, "People do not deserve things on account of their willingness to work, but only on account of their actually having worked." 24 There are reasons for saying this, and Rachels may be right when speaking of rewards. It appears analytic that rewards respond to past performance. However, rewards are not the only kind of thing that can be

\footnotetext{
${ }^{20}$ Feldman $(1995,70-71)$ argues that a soldier who volunteers for a suicide mission can deserve a medal in advance. (Feldman is still talking here about deserving rewards. He does not claim people deserve opportunities.) Jeremy Waldron and Fred Miller see forward-looking elements in Aristotle's discussion of meritocracy in distributing political offices. Aristotle (Politics 3.12.1282b. 30) says, "When a number of flute players are equal in their art, there is no reason why those of them who are better born should have better flutes given to them; for they will not play any better on the flute, and the superior instrument should be reserved for him who is the superior artist." See Fred D. Miller (2001). Intriguingly, Waldron suggests a school might choose among candidates by comparing how meritorious the school would be if it hired one rather than another. See Waldron (1995) 573.

${ }^{21}$ Rachels (1997) 176.

${ }^{22}$ Rachels (1997) 180.

${ }^{23}$ An important caveat: although Rachels and David Miller (1976) say what we deserve depends on what we did in the past, and never on the future, it would be anachronistic to interpret them as rejecting my proposition that we can deserve $\mathrm{X}$ in virtue of what we do after receiving X. At the time, it had not yet occurred to anyone to be for, or against, my proposition. My main aim here is not to defend the proposition against bitter enemies, but simply to introduce it as a possible position.

${ }^{24}$ Rachels (1997) 185
} 
deserved. We sometimes have reason to say "She deserves a chance." We may say a young job candidate deserves a chance not because of work already done but because she is plainly a talented, well-meaning person who wants the job and who will throw herself into it if given the chance.

A more senior internal candidate for a job may be deserving in a different way: that is, worthy of reward for past performance. Yet, the idea that an inexperienced candidate can deserve a chance, for the reasons mentioned, is something most people find compelling. We can be glad they do, too, insofar as thinking this way leads them to give opportunities to people who are worthy in the promissory sense, that is, people who, when given a chance, give the opportunity its due. ${ }^{25}$

If we say a job candidate deserves a chance, and then, far from throwing herself into the job, she treats it with contempt, that would make us wrong. The promissory aspect of desert will have failed to materialize. She had a chance to balance the account and failed. If she treats the job with contempt, then she supplies neither the performance nor even the good faith effort the hiring committee expected.

By contrast, if the candidate fails through no fault of her own, then we cannot hold it against her. And if her failure is simply a stroke of unforeseeable bad luck, then neither can the committee blame themselves for having chosen wrongly. They may say in retrospect that although the new employee failed to do justice to the opportunity, it was because she did not really get the opportunity the committee intended. By analogy, suppose we intend to give salt a chance to dissolve in water, but what we actually end up doing is giving salt a chance to dissolve in olive oil. If the salt fails to dissolve, we still insist the salt would have dissolved in water, given the chance.

The possibility of bad luck notwithstanding, the fact remains that we sort out applicants for a reason. In normal cases, the point is not to reward someone for past conduct but to get someone who can do the job. That is why, by the time we reach $t_{2}$, the question is not what she did before the opportunity but what she did with it. The question at $t 2$ need not and normally does not turn on what was already settled at $t_{1}$.

A note on examples. Realistic examples are complex, raising issues beyond those intended by the theorist who brings them up. In this case, real-world hiring committees must juggle several criteria, not all of them having to do with desert. Some points might be better illustrated by speaking of tenure and promotion committees, where decisions are more purely a matter of desert but where candidates have enough of a history that it is harder to sort out backward- versus forward-looking grounds for judging whether a candidate is deserving. Candidates often see their case as purely backward looking, but tenure committees do not. Tenure committees want to know that a candidate will not become deadwood-that past performance was not spurred mainly by a prospect of tenure qua reward. They want to be able to

\footnotetext{
${ }^{25}$ Not all true statements about what we deserve have the status of desert claims. Claims in the relevant sense imply correlative duties, such as the duty to give claimants what they deserve. Someone who says Jane did justice to her opportunity may be expressing a truth without meaning to be making a claim on Jane's behalf against anyone else.
}

look back years later and say the candidate deserved tenure qua opportunity.

\section{REFINING THE PROMISSORY MODEL}

To further clarify the nature of the promissory model, we should separate it into two elements. The first explains what we can say about Jane from the perspective of $t_{2}$. The second explains what we can say about her from the perspective of $t_{1}$.

Element (a): A person who receives opportunity $\mathrm{X}$ at $t_{1}$ can be deserving at $t_{2}$ because of what she did when given a chance.

Element (b): A person who receives opportunity $\mathrm{X}$ at $t_{1}$ can be deserving at $t_{1}$ because of what she will do if given the chance.

What does element (a) tell us? It tells us that it can be true at $t_{2}$ that the account has been settled. Jane supplied inputs that did justice to $\mathrm{X}$. We need not suppose Jane supplied those inputs at $t_{1}$. When we call Jane deserving at $t_{2}$, as per element (a), we are not denying that she may have been merely lucky at $t$. All we are saying is that when Jane got the chance to prove herself worthy, she did so.

Element (a) concerns what Jane can do to be deserving at $t_{2}$ even if she was merely lucky at $t_{1}$. By contrast, element (b) concerns how Jane can deserve $\mathrm{X}$ at $t_{1}$ not as a reward for past performance but as an opportunity to perform in the future. In other words, element (b) concerns how a committee nonarbitrarily could select Jane in preference to some other candidate. Jane is choice-worthy if she is the sort of person who will do justice to the opportunity. She may be choice-worthy in virtue of past performance, but a search committee is not trying to reward past performance. They are trying to decide whether to count Jane's past performance as evidence that she will do justice to opportunity $\mathrm{X}$-evidence that she will settle the account, given the chance.

There are various ways to formulate element (b). None are perfect. However, when we think of contexts like hiring decisions, it is natural to say a hiring committee is looking not merely for someone who theoretically can do the job, but for someone who will do the job given a chance, meaning she will do the job if we offer it to her, if she accepts it, if there is no unforeseen catastrophe, and so on. Our invocation of element (b) at $t_{1}$ is essentially a prediction that by the time we get to $t 2$, we will be in a position to invoke element (a). We are predicting that by $t_{2}$, Jane will have supplied the relevant desert-making inputs. However, we are not merely wagering on future performance. Rather, we are wagering that Jane has desert-making internal features that will translate into future performance, barring unexpected misfortune. We are judging that Jane is the kind of person who will do the job given the chance. ${ }^{26}$

Element (a) says that although desert requires a balance between what Jane gives and what Jane is given, Jane need not move first. Element (b) says Jane can deserve

\footnotetext{
${ }^{26}$ When we think a machine will perform well if we give it a chance, we do not say the machine deserves a chance. We may say "It is worth a try," but we do not mean the same thing when speaking of a person's character as when speaking of a machine's characteristics. I owe this point to Michael Smith.
} 
opportunity $\mathrm{X}$ (in the sense of being choice-worthy) before she does her part. Element (a), by contrast, pointedly does not say Jane can deserve $\mathrm{X}$ before doing her part. Element (a) stresses that even if Jane deserves $\mathrm{X}$ only after doing her part, it still does not follow that she has to do her part before receiving $X$.

Element (a) therefore is the essence of the promissory model. So far as our purpose is to challenge the ideas that we deserve $\mathrm{X}$ only if we deserve it as a reward for past performance, and that we cannot deserve $X$ except in virtue of what we do before receiving $X$, we do not need element (b). We need some version of element (b) only insofar as we further seek to vindicate our ordinary practice - in particular our tendency to speak of candidates as deserving a chance in virtue of what they can and will do if we give them a chance. $^{27}$

I said there are various ways of formulating element (b), and none are perfect. In spelling out element (b), we could interpret choice-worthiness as a question of either what is true of the candidate or what the committee justifiably believes about the candidate. ${ }^{28}$ There are pros and cons either way. We may sometimes have reason to distinguish evidence that Jane will do well from the fact (if and when it becomes a fact) that Jane will do well. What makes Jane choice-worthy in the metaphysical rather than the epistemological sense is the fact that she truly is the kind of person who (barring unforeseen catastrophe) would supply the requisite desert makers and thus become deserving at $t_{2}$ in the sense of element (a).

If a committee concludes that Jane is choice-worthy at $t_{1}$, then whether the committee judged correctly (that is, whether it truly picked the right person, as opposed to whether its members were justified in believing they picked the right person) remains to be seen. Is this a puzzle? If so, it is less a puzzle about desert and more a puzzle about prediction in general. Suppose at $t_{1}$ we say Jane will be married at $t_{2}$. Jane then gets married. In that case, events at $t_{2}$ have indeed settled the truth-value of a claim uttered at $t_{1}$. Does anyone find this puzzling? The future event does not backward-cause the prediction to be true; it simply settles that the prediction was true. Events at $t 2$ can settle the truthvalue of a claim like "She'll get married, given a chance." They also can settle the truth-value of a claim like "She'll do justice to $X$, given a chance." There comes a time when we can say "You said she'd get married; it turns out you were right," or when a committee can say "We said she'd do justice to the opportunity; it turns out we were right." In either case, Jane settles what had been unsettled. Saying "She deserves X," meaning she will do justice to X given a

\footnotetext{
27 David Miller comes as close as any philosopher ever has, to my knowledge, to endorsing element (b). Miller says there are insuperable obstacles to interpreting jobs as rewards for past conduct $(1999 \mathrm{a}, 159)$. When we say someone deserves a prize, we standardly base our judgment on past or present performance, but when we are making hiring decisions, the best-qualified candidate, the one who deserves it, is the one who will perform it best, other things being equal (162). And "in the case of jobs past performance matters only as a source of evidence about a person's present qualities" (170).

${ }^{28}$ Recall David Miller's (1976) claim that "desert judgments are justified on the basis of past and present facts about individuals." I can agree that the epistemological justification of desert claims is backward looking, because that is where the information is, while still holding that truth makers for some desert claims can lie in the future. (We would say the same of predictions in general.)
}

chance, is no odder than saying "Salt is soluble," meaning it will dissolve in water given a chance.

Insofar as the idea that Jane deserves a chance at $t_{1}$ depends on whether Jane has relevant dispositional properties at $t 1$, and insofar as a test of this idea lies in the future, element (b) implies that life sometimes involves decision-making under uncertainty. Hiring committees judge which candidate is most worthy, with no guarantee that they are judging correctly.

When a committee judges at $t_{1}$ that Jane deserves a chance, they are placing a bet. They are judging her character. They may even transform her character, insofar as their trust may inspire her to become the kind of person they judge her to be. At $t_{1}$, though, it remains to be seen whether Jane is or will become that kind of person. Jane settles that later, in an epistemological sense, and perhaps (more intriguingly) in a metaphysical sense, too, insofar as she must decide, not merely reveal, whether she really is that trustworthy, that hardworking, and so on. The committee will have to wait and see. Since life truly is difficult in this way, we can be glad to have a theory that correctly depicts the difficulty - that does not make life look simpler than it is. $^{29}$

In passing, what can the promissory model say about unsuccessful candidates, or more generally about people who lack opportunity? What if there are more deserving candidates than positions for them to fill? Element (a) is silent on questions about people who never get a chance, but element (b) can say about unsuccessful candidates roughly what it says about successful ones; namely, they may deserve $\mathrm{X}$ insofar as they, too, would have done justice to $\mathrm{X}$, given a chance. My theory does not say people who lack opportunities are undeserving. (Recall the salt analogy. When salt fails to dissolve in olive oil, we do not conclude that salt is not water-soluble. We acknowledge that it never got the chance, perhaps adding that we still believe in salt's water-solubility, meaning we believe it would have dissolved in water given the opportunity.)

Also in passing, would I entertain a promissory theory of punishment? ("He may be innocent now, but if we put him in jail, he'll become the sort of person who belongs in jail.") No. We may view reward and punishment as two sides of the same compensatory coin, but there is no such parallel between opportunity and punishment. The transformative role of expectations (the fact that we tend to live up to them, or down, as the case may be) can justify the faith involved in granting an opportunity but cannot justify punishment. ${ }^{30}$ If Jean Valjean wrongly is imprisoned and says, "Okay, if they treat me like a criminal, I'll act like one," this does not vindicate the wrongful punishment. Indeed, the fact that the punishment induces punishment-worthy behavior further condemns the punishment. By contrast, if Valjean later is rocked by a bishop's kindness and says, "Okay, if they treat

\footnotetext{
${ }^{29}$ I thank Guido Pincione and Martín Farrell for their insight on this point.

${ }^{30}$ George Rainbolt suggests that my promissory model may have a greater range of explanatory power than I give it credit for. In particular, if we have good reason to believe that a prisoner convicted of a violent crime is unrepentant and indeed intent on repeating his crime upon being paroled, that is a reason for not granting parole. It is a reason not only in the sense that society has a right to protect itself from a confirmed and unreformed violent criminal but also in the sense that the prisoner is undeserving of parole.
} 
me like a decent human being, I'll act like one," that does vindicate the bishop's kindness. ${ }^{31}$

According to my theory, there is something slightly misleading, or at best incomplete, in assessing a society by asking whether people get what they deserve. If desert matters, then often a better question is whether people do something to deserve what they get. Do opportunities go to people who will do something to be worthy of them?

My purpose here is to make room within a credible theory of justice for the idea that there are things we can do to be deserving. Specifically, we can deserve an opportunity. Moreover, whether we deserved an opportunity can depend on what we did with it. First, there are things we can do after the fact to balance the scale, making it fitting in retrospect that we got a chance to prove ourselves at $t_{1}$. Second, we can be choice-worthy even at $t 1$, insofar as a committee can see (or insofar as it is true) that we will do justice to the opportunity. The latter is not the core of my theory of desert, but it is a way of pushing the envelope and making sense of a central part of ordinary life.

\section{DESERVING AND EARNING}

We commonly show our respect for what a person has achieved by saying "You deserved it" or "You earned it." The words 'deserving' and 'earning' are nearly interchangeable in ordinary use. There is a difference, though, and it will be useful to give the difference a bit more emphasis than it gets in ordinary use.

A paycheck is not earned until the work is done. Upon being hired, I will do what I need to do to earn the paycheck, but the future does not settle that I have earned the paycheck now. I have not earned it until I do the work. Thus, while we do speak of people as deserving a chance even before they supply the requisite inputs, we do not speak of people as having earned a paycheck prior to supplying requisite inputs.

Perhaps this is because what Jane deserves has more to do with her character, whereas what Jane has earned has more to do with her work. Jane's character can be manifest before she supplies the requisite inputs. Her work cannot similarly be manifest prior to supplying requisite inputs, since her work is the requisite input when the question concerns what she has earned. Jane can be deserving at $t_{1}$ in virtue of what she will do, if given a chance. To have earned a paycheck at $t_{1}$, though, she has to have done the work at $t_{1}$.

Therefore, that she would earn the check at $t_{2}$ is not relevant to what Jane has earned at $t_{1}$, even thoughaccording to element (b) - it is relevant to whether she deserves a chance at $t_{1}$. Thus, the promissory model does not, at $t_{1}$, work for earning. There is no analog of element (b).

However, there is an analog of element (a). We acknowledged that I have not earned the paycheck until I do the work. Does that mean I can earn the check only if I do the work first, before the check is issued?

No! In everyday life, we do not doubt that a new but trusted employee, paid in advance, can earn the money after the fact. Money is paid at $t_{1}$, then what was not true at $t_{1}$

\footnotetext{
${ }^{31}$ Jean Valjean is a character from Victor Hugo's novel Les Misérables.
}

becomes true at $t_{2}$ : namely, the scale is now balanced and money given at $t_{1}$ has been earned. It becomes true at $t_{2}$ that Jane did what she was paid to do.

Therefore, we cannot save the academic convention that desert is a purely compensatory notion by recasting it as a thesis about earning. It does not capture the concept of desert. It does not work for earning either. ${ }^{32}$

An unearned opportunity is an unearned opportunity, but though unearned, a person may yet do justice to it. That possibility often is what we have in mind when we say a person deserves a chance. To ignore that possibility is to ignore the possibility of redemption involved in working to do justice to an opportunity.

In a popular film about World War II, Saving Private Ryan, Captain Miller is fatally injured while rescuing Private Ryan. As Miller dies, he says to Ryan: "Earn it!" At that moment, neither character is under any illusions about whether Ryan earned the rescue. He did not, as they both know. Neither is Ryan choice-worthy in the sense of element (b), as they both know. (As the story goes, the reason High Command orders Ryan's rescue has nothing to do with Ryan's worthiness. Ryan's three brothers have just died in battle. The point of rescuing Ryan is to avoid having to send a telegram to Ryan's mother saying her entire family has just been wiped out.) Still, as both characters also know, that is not the end of the story, for it is now up to Ryan to settle whether Miller's sacrifice was in vain. ${ }^{33}$ It is not too late for Ryan to try to redeem the sacrifice by going on to be as worthy as a person could be. ${ }^{34}$

If there is anything Ryan can do to earn the rescue, it will be at $t_{2}$, not $t_{1}$, as analogous to the promissory model's element (a). When Miller says "Earn it," he fully realizes that Ryan has not yet done his part. Ryan's rescue can never be deserved in the way a reward or prize is deserved. To be earned (deserved) at all, the rescue will have to be earned in the way advance salary is earned: that is, after the fact.

Fittingly, the film ends with a scene from decades later. An elderly Ryan visits Miller's grave. Anguished, Ryan begs his wife: "Tell me I've been a good man!" The implication: if Ryan has been a good man, then he has done all he could to earn the rescue that gave him a chance to be a good man. Notice that Ryan's story is neutral regarding the relevance of alternative desert bases. The elderly Ryan's wife may say the relevant basis is effort and thus that Ryan is deserving in virtue of having done all he could. Ryan himself may see achievement as the relevant basis, and conclude that despite his efforts he has not done nearly enough to be worthy of all

\footnotetext{
${ }^{32}$ However, we might defend a version of Feldman's (1995) thesis in this way. The soldier awarded a medal in advance does not deserve it and has not earned it. (The medal is an award, not an opportunity. If it is deserved at all, it must be deserved qua award, which is to say it must be deserved along lines specified by the compensatory model.) Even so, it can make sense to honor the soldier now for what the soldier is about to do. Then, after the soldier makes the heroic sacrifice, it will make sense to speak of the soldier as having earned the medal.

${ }^{33}$ Abraham Lincoln's Gettysburg Address, one of the most moving speeches ever made, gains its rhetorical power from precisely this point, speaking as it does of the unfinished work of those who died in battle, calling on us to make sure their "last full measure of devotion" shall not be in vain.

${ }^{34}$ Here is another way of interpreting what Captain Miller means when he says "Earn it." Miller is saying Ryan owes it to the men who died to be as worthy as possible of their sacrifice. So interpreted, Miller's question invokes compensatory as well as promissory models. Going on to be as worthy as possible is the closest Ryan can come to giving the fallen soldiers what they deserve in recognition of their sacrifice. I owe this thought to an email exchange with Bas van der Vossen.
} 
the lives that were sacrificed to save his. The problem is general. If great sacrifices were made so as to put us in a position to flourish, we have to wonder whether there is anything we can do to be worthy of those sacrifices. The easy answer is that if we do all we can, we have done all anyone could ask. Yet, if we are reflective, we cannot help but think the easy answer sometimes is too easy, and that there is no guarantee that "doing all we can" will be enough.

Good luck cannot rob us of the chance to act in ways that make people deserving, although bad luck can, which is one reason bad luck is bad. For example, if Private Ryan is killed by a stray bullet within minutes of being rescued, then there is no fact of the matter about whether Ryan did justice to the opportunity to live a good life, since (in this scenario) he got no such opportunity. Bad luck robbed him of it.

In some ways, Ryan's situation is like a lottery winner's. If Miller hands Ryan a winning lottery ticket and says with his dying breath "Earn it," can Ryan earn it? No one would say Ryan has earned it at $t_{1} ;{ }^{35}$ but that is not the end of the story, because even when a windfall is sheer luck, it is not only sheer luck. It is also a challenge, and as with most challenges, there is a right way of responding. Some day, there will be a fact of the matter regarding whether Ryan responded well.

Private Ryan's situation also is a bit like that of persons born with natural and positional advantages. We are not born having done anything to deserve advantages as rewards. So, a standard compensatory model has no resources to underwrite claims of desert at the moment of birth. At birth, we are merely lucky. (Neither is there any basis for deeming us choice-worthy, if choosing were even an issue.) Still, regarding our advantages, there is something we can do later on. We can do justice to them.

\section{GROUNDING DESERT}

Are the two models, compensatory and promissory, truly models of desert? Does it matter? The main issue is not whether we use the same word when referring to those who did their best before receiving rewards and to those who did their best after receiving opportunities. In fact, we do, but the larger question is whether we are justified in thinking of desert claims as weighty in both cases.

I explained how in everyday life we grasp the concept of deserving a chance in virtue of what we did, or will do, with it. I would not appeal to common sense to justify our common-sense understanding, though. To justify, we look elsewhere. This section indicates (although only indicates) where we might look.

Part of what makes it difficult even to begin such a discussion is that in trying to justify, we risk trivializing. We risk seeming to ground a thing in considerations less important than the thing itself. That could be a problem when trying to justify a conception of justice. When assessing alternative conceptions of justice, we generally cannot settle the contest by appeal to yet another lofty but

\footnotetext{
${ }^{35}$ If the case were more like the kind of case covered by element (b), Captain Miller conceivably might say Ryan deserves the ticket. For example, suppose Miller needs to select someone from a list of applicants, and sees that Ryan would move mountains to prove himself worthy. In that case, deeming Ryan choice-worthy on that basis might be Miller's best-justified option.
}

contested ideal of justice. However, if we appeal to something else-something other than (our conception of) justice-we are bound to be appealing to that which seems less important. But that is all right. We are not confusedly seeking the foundation of that which is itself foundational. We simply ask what can be said on the conception's behalf.

\section{The Least Advantaged}

Margaret Holmgren says justice "demands that each individual be secured the most fundamental benefits in life compatible with like benefits for all," and then adds, "the opportunity to progress by our own efforts is a fundamental interest." ${ }^{36}$ Richard Miller concurs: "Most people (including most of the worst off) want to use what resources they have actively, to get ahead on their own steam, and this reflects a proper valuing of human capacities." 37

On one view, the Rawlsian supposition that inequalities should be arranged to maximally benefit the least advantaged rules out the idea that people deserve more - and thus should get more-if and when and because their talents and efforts contribute more to society. Holmgren, though, notes that contractors in Rawls's original position would know (because by hypothesis they are aware of perfectly general features of human psychology) that people not only want to be given stuff; they want to be successful, and they want their success to be deserved. Accordingly, even contractors who are so grossly risk-averse that they focus only on the least advantaged economic class would still want to ensure that least advantaged people have an opportunity to advance by their own efforts. What would such contractors choose? Holmgren says, "Rather than focusing exclusively on the share of income or wealth they would receive, they would choose a principle of distribution which would ensure that they would each have this opportunity." 38

Holmgren's claim seems incompatible with Rawls's difference principle, if we interpret the principle as Nozick interprets it, as a ground-level prescription for redistribution. In that case, the idea that Jane deserves her salary threatens to override our mandate to lay claim to her salary on behalf of the least advantaged. However, Nozick's way is not the only way to interpret the difference principle. Suppose we interpret the principle not as a mandate for redistribution but rather as a way of evaluating basic structure. That is, we evaluate basic structure by asking whether it works to the benefit of the least advantaged. On the latter interpretation, we choose among rules like "Try to give people what they deserve" and "Try to give the least advantaged everything" by asking which is best for the least advantaged in actual empirical practice.

The latter undoubtedly is the difference principle's canonical interpretation. Unfortunately, we naturally slip into thinking of bargainers as choosing a plan for redistribution. Rawls himself slips in this way when he says, "There is a tendency for common sense to suppose that income and wealth, and the good things in life generally, should be distributed according to desert. . . . Now justice as fairness rejects this conception. Such a principle would not be chosen

\footnotetext{
${ }^{36}$ Holmgren (1986) 274

${ }^{37}$ Richard Miller (2002) 286

${ }^{38}$ Holmgren (1986) 275.
} 
in the original position." 39 The conclusion is right, but the argument leading to it is not. We can agree that such a principle would not be chosen, but the reason is because distributional principles per se are not on the menu. They are not even the kind of thing bargainers choose. Bargainers choose metalevel principles for evaluating principles like distribution according to desert.

Read in this canonical way, the difference principle, far from competing with principles of desert, can support the idea that people deserve a chance. The difference principle supports principles of desert if Holmgren is correct to say the least advantaged want and need the chance to prosper by their own merit. Likewise, the difference principle supports principles of desert if it is historically true that the least advantaged tend to flourish within, and only within, systems in which honest hard work is respected and rewarded. Such a system may be the best that unskilled laborers could hope for: best for them as wage laborers, as consumers of what other workers produce, as parents who believe their children deserve a chance, and perhaps also as people who may one day need the kind of safety net (private or public insurance) that only a booming economy can afford. Rawlsians and non-Rawlsians alike can see these considerations as weighty.

\section{Utility}

Likewise, utilitarians and nonutilitarians alike can care about consequences. Feinberg says, "The awarding of prizes directly promotes cultivation of the skills which constitute bases of competition." ${ }^{40}$ Rawls says, "Other things equal, one conception of justice is preferable to another when its broader consequences are more desirable." ${ }^{, 1}$ So, both Feinberg and Rawls can correctly insist that utility is not a desert maker, while also recognizing that (a) things that are desert makers (effort, excellence) can as a matter of fact make people better off, and that (b) making people better off is morally significant. Rachels adds,

In a system that respects deserts, someone who treats others well may expect to be treated well in return, while someone who treats others badly cannot. If this aspect of moral life were eliminated, morality would have no reward and immorality would have no bad consequences, so there would be less reason for one to be concerned with it. ${ }^{42}$

In short, our ordinary notions of desert serve a purpose. One (if only one) way a society benefits people is by distributing fruits of cooperation in proportion to contributions to the cooperative effort. That is how societies induce contributions to begin with. Desert as normally understood is part of the glue that holds society together as a productive venture. Respecting desert as normally understood (respecting the inputs people supply) makes people in general better off. To be sure, it would be a misuse of terms to say Bob deserves a pay raise on the grounds that giving him a raise would have utility. We may say Bob deserves a raise because he does great work, does more than his share, and does it without complaint. We do not say giving Bob a raise would have utility. But if we ask why we should acknowledge that Bob is a great worker, a big part of

\footnotetext{
${ }^{39}$ Rawls (1971) 310.

${ }^{40}$ Feinberg (1970) 80

${ }^{41}$ Rawls (1971) 6.

${ }^{42}$ Rachels (1997) 190
}

what makes Bob's efforts worthy of recognition is that his efforts are of a kind that make us all better off. If we ask why Bob is deserving, the answer should be: Bob supplied the requisite desert makers. If we ask why we care whether Bob supplied inputs that make a person deserving, one answer would be: supplying those inputs makes Bob the kind of person we want our neighbors, our children, and ourselves to be, and makes us all better off to boot.

The point need not be to maximize utility so much as to show respect for customs and institutions and characters that make people better off. (Either way, desert tracks constructive effort rather than effort per se. Effort-tokens need not be successful, but they do need to be of a type that tends to produce worthy results.) If we are to do justice to individual persons, then when their individuality manifests itself in constructive effort, we had better be prepared to honor that effort, and to respect the hopes and dreams that fuel it.

\section{Need}

When we say "She deserves a chance," how does that differ from saying she needs a chance? "Deserves" suggests she has some realized or potential merit in virtue of which she ought to be given a chance, whereas "needs" suggests neither real nor potential merit. However, when we say "All she needs is a chance," that comes close to saying she deserves a chance. It comes close to saying she is the kind of person who will give the opportunity its due.

Nonetheless, whatever room we make for desert, the fact remains that people's needs matter, at least at some level. ${ }^{43}$ In fact, I would go so far as to say that desert matters partly because needs matter. That Bob needs $X$ is no reason to say Bob deserves $X$ for the same reason that X's utility is no reason to say Bob deserves $X$. And if that is true, then need is not a desert base. But there are other ways for need to be relevant.

Suppose, for simplicity's sake, that the only way to deserve $\mathrm{X}$ is to work hard for $\mathrm{X}$. In that case, by hypothesis, need is not at all relevant to whether Bob deserves X. By hypothesis, all that matters is that Bob worked hard for X. Still, even though by hypothesis need has nothing to do with our reason for thinking Bob deserves $\mathrm{X}$, need remains a reason for caring about desert. One reason to give people what they deserve is that it renders people willing and able to act in ways that help them (and the people around them) to get what they need. Welfare considerations are not desert bases, but they can still provide reasons for taking a given desert maker seriously (e.g., for respecting people who work hard).

\section{Dignity}

When wondering whether a person did justice to an opportunity, we typically do not look back to events that occurred before the opportunity was received. I indicated how we might argue for this on consequentialist grounds. It may be a good thing on Kantian grounds, too. Although I will not press the point, there is something necessarily and laudably ahistorical about simply respecting what people bring to the table. We respect their work, period. We admire

\footnotetext{
${ }^{43}$ I am agreeing here with, among others, Brock (1999) 166.
} 
their character, period. We do not argue (or worse, stipulate as dogma) that people are products of nature/nurture and thus ineligible for moral credit. Sometimes, we simply give people credit for what they achieve, and for what they are. And sometimes, simply giving people credit is the essence of treating them as persons rather than as mere confluences of historical forces.

Part of the oddity in doubting whether Jane deserves her character is that Jane's character is not something that happened to her. It is her. Or if we were to imagine treating Jane and her character as separate things, then it would have to be Jane's character that we credit for being of good character, so the question of why Jane per se should get the credit would be moot. In truth, of course, it is people, not their characters, that work hard. Thus, if we say exemplary character is morally arbitrary, it is people, not merely character, that we are refusing to take seriously.

Martin Luther King once said, "I have a dream that my four children will one day live in a nation where they will not be judged by the color of their skin but by the content of their character." ${ }^{44}$ This was a dream worth living and dying for. King did not dream his children would live in a nation where their characters would be seen as accidents for which they could claim no credit. King asked us to judge his children by the content of their character, not by its causes. That was the right thing for King to ask, because that is how we take characters (that is, persons) seriously.

If the characters of King's children are not taken seriously, they will get neither the rewards nor the opportunities they deserve. Especially by the lights of Rawls's difference principle, this should matter, for the least advantaged can least afford the self-stifling cynicism that goes with believing no one deserves anything. Neither can they afford the license for repression that goes with the more advantaged believing no one deserves anything.

These remarks indicate that the possibility of deserving a chance is not mere common sense. In the end, the bottom line is in part a practical question, somewhat amenable to empirical testing: which way of talking-about what people can do to be deserving-empowers people to make use of their opportunities?

\section{DESERT AS AN INSTITUTIONAL ARTIFACT}

To Feinberg, "desert is a natural moral notion (that is, one which is not logically tied to institutions, practices, and rules). ${ }^{45}$ Rawls denies that desert is natural in this sense, but concedes the legitimacy of desert claims as institutional artifacts. Thus, faster runners deserve medals according to rules created for the express purpose of giving medals to faster runners. Those who have done what the system announces it will reward are entitled to have their expectations met. In this sense the more fortunate have title to their better situation; their claims are legitimate expectations established by social institutions and the community is obligated to fulfill them. But this sense of

\footnotetext{
${ }^{44}$ Martin Luther King, August 28, 1963. Washington D.C. See King (1986).

${ }^{45}$ Feinberg (1970) 56.
}

desert is that of entitlement. It presupposes the existence of an ongoing cooperative scheme. ${ }^{46}$

The idea is that at some point we will be in a position to define, then acknowledge, claims of desert; but such claims (1) will have no standing outside the context of particular institutional rules, and therefore (2) cannot bear on what rules we should have in the first place. ${ }^{47}$

Other senses of desert, though, are less closely tied to institutional structures. A medalist who trains for years deserves admiration in a way a medalist who wins purely on the strength of genetic gifts does not, even when the two are equally deserving of medals by the lights of the institutional rules. Likewise, athletes prove themselves worthy of their families' and coaches' faith by doing all they can to win, and by being role models in the process, even when institutional rules are silent on the relevance of such inputs.

Consider this case. Canadian sprinter Ben Johnson ran the fastest time in the 100-meter race at the 1988 Olympics. Did he deserve a gold medal? He did nothing to show that he deserved his genetic gifts, or his competitive character, or the excellence of his coaches. All he did was run faster than the competition, which on its face entailed that he deserved gold.

However, blood tests revealed that Johnson had taken steroids. Did it matter? Yes. The fact that he took steroids raised questions of desert, whereas the bare fact that Johnson had a background (he had genes; he grew up in an environment) did not. Being born in the wake of the big bang did not stop Johnson from deserving a medal, but there is a real question about whether taking steroids preempts inputs by which sprinters come to deserve medals. We may ask whether steroids are in fact banned. That is an institutional question. We also may ask whether steroids should be banned. That question is preinstitutional: its answer (1) does not turn on particular institutional rules, and (2) does bear on what rules we should have in the first place.

As noted, Rawls says those who do what the system announces it will reward are entitled to have their expectations met. Rawls insists the status of such expectations is an institutional artifact. He is right in one way and wrong in another. On the one hand, it is an institutional artifact that the winner is entitled to gold rather than platinum. On the other hand, it is a preinstitutional moral fact that if the system promises a gold medal to the winner, then the system ought to give the winner a gold medal.

Notice that the system need not announce an obligation to keep promises. It has that obligation regardless. Therefore, while many of the factors that go into determining entitlements may be institutional artifacts, this one is not.

\footnotetext{
${ }^{46}$ Rawls $(1999,89)$. In the 1971 edition, the final sentence reads: "But this sense of desert presupposes the existence of an ongoing cooperative scheme " $(1971,103)$. So the explicit assimilation of desert to entitlement came later. However, the next paragraph of the 1999 edition makes a further change that goes in the opposite direction, as if unaware of the change to the previous paragraph. Rawls says in that next paragraph that we do not deserve our social endowments, or even our character, "for such character depends in good part upon fortunate family and social circumstances in early life for which we can claim no credit. The notion of desert does not apply here. To be sure, the more advantaged have a right to their natural assets, as does everyone else" $(1999,89)$. The last sentence is a new addition, separating desert, which does not apply, from entitlement, which evidently does.

${ }^{47}$ Rawls (1971) 103
} 
Obviously, some desert claims carry moral weight as institutional artifacts. (It makes sense for a winner to claim to deserve a platinum medal only if that is what the system has led the winner to expect.) However, some claims do not merely happen to carry weight as institutional artifacts. They should carry weight as institutional artifacts because they carry weight preinstitutionally. It is a matter of indifference whether the system promises the winner gold or platinum. It is not a matter of indifference whether the system encourages excellence rather than corruption or incompetence. We see winning sprinters as deserving when we see their excellence as a product of years of ferocious dedication. If instead we thought the key to winning was more drugs, we would not regard winners as deserving. This difference is not an institutional artifact. We see the cases differently even when a performance-enhancing drug is allowed by the rules.

Part of our reason for caring is that the race's point is to show us how excellent a human being can be. If we explain success in terms of steroids rather than in terms of features of persons that ground desert claims in a preinstitutional sense, the institution is not working. If the competition inspires impressionable viewers to take steroids rather than to develop their talents, the institution is not working. If one way of competing risks competitors' lives and sets a dangerous example for children who idolize them, while a version that bans steroids is healthier for everyone, then we have preinstitutional grounds for thinking it was right to establish, publicize, and enforce the ban, and that my compatriot Ben Johnson did not deserve a medal. ${ }^{48}$

\section{THE LIMITS OF DESERT}

As mentioned earlier, this essay's purpose is to offer a nonskeptical conception of desert for those who wish to make room in a philosophically respectable theory of justice for the idea that there are things we can do to be deserving. (To be sure, not everyone does wish to make room for this idea.) Specifically, it is possible for Jane to deserve an opportunity. And whether Jane deserved an opportunity can depend at least partly on what she did with it. It is crucial that the scales be balanced. It is not crucial that components of the balance be supplied in a particular order. If $\mathrm{X}$ is conferred first, and the desert base is supplied later, that, too, is a balancing of the moral scale.

The import of the promissory model's element (a) is that what once was morally arbitrary need not remain so. The most valuable things we are given in life are opportunities, and the main thing we do to deserve them is to do justice to them after the fact. The import of element (b) is that this theory has room for the common-sense idea that people can deserve a chance. They can deserve a chance not because of what they have done but because of what they can and will do, if only we give them a chance.

We need to keep these conclusions in perspective, though. It is a core feature of my overall theory of justice that what I call "deserving a chance" is not the whole of desert. Desert is not the whole of justice. Justice is not the whole of morality. This part of a larger theory tells us to treat

\footnotetext{
48 This conclusion does not presuppose the promissory model. The possibility of preinstitutional desert is manifest even within the compensatory framework.
}

opportunities as challenges and to respect those who meet their own challenges in fitting ways, but this part does not answer all questions. It does not say what Wilt Chamberlain should have been paid, or what opportunities Wilt should have had. It answers one question: What can Wilt or anyone blessed by good fortune do to be deserving? Its answer is: when we look back on Wilt's career, wondering whether he deserved his advantages, we are not restricted to considering what he did before receiving them. What matters, if anything matters, is what he did with them.

So, did Wilt Chamberlain do justice to the potential given to him by luck of the draw in the natural lottery ${ }^{49}$ One possible answer is that whether he did justice to his potential is no one else's business. Wilt is not indebted to anyone for his natural assets. He did not borrow his talent from a common pool. No account is out of balance merely in virtue of Wilt having characteristics that make him Wilt. Still, even if it is no one else's business whether Wilt does justice to his potential, the fact remains that one way or another, Wilt will do, or fail to do, justice to it.

Part of our reason for thinking it is Wilt rather than you or me who deserves credit for the excellence of Wilt's performance is that, as David Miller puts it, "the performance is entirely his." ${ }^{50}$ Note that the issue is not whether the performance is Wilt's rather than the big bang's; the issue is whether the performance is Wilt's rather than some other person's. The question of whether to credit Wilt for his performance is never a question of whether Wilt caused himself to have his character and talent. Instead, the question is whether the character, talent, or other desertmaking inputs are, after all, Wilt's rather than some other person's. 51

If and when we applaud Wilt's effort, we imply that the credit is due to Wilt rather than to, for example, me. Why? Not because Wilt deserved the effort (whatever that means) or deserved the effort more than I did (whatever that means) but because the effort was Wilt's rather than mine. When we ask whether the effort is truly Wilt's, the answer sometimes is simply yes. Other times, we credit Wilt's coaches or parents for performances that contributed to Wilt's in tangible ways. ${ }^{52}$

Notice that giving credit is not a zero-sum game. We do not think less of Wilt when Wilt thanks his parents. Indeed, we think less of Wilt if he fails to give credit where credit is due. The credit due to Wilt's parents takes away from credit due to Wilt only if the implication is that the performance we thought was Wilt's was not really his. (Imagine Wilt, in an acceptance speech for an academic award, naively thanking his coaches and parents for writing all those term papers.)

\footnotetext{
${ }^{49}$ I thank Paul Dotson and Peter Dietsch for discussions about what is involved in having status as a person.

${ }^{50}$ Miller (1999a) 144.

${ }^{51}$ Beitz says, "While the distribution of natural talents is arbitrary in the sense that one cannot deserve to be born with the capacity, say, to play like Rubinstein, it does not obviously follow that the possession of such a talent needs any justification. On the contrary, simply having a talent seems to furnish prima facie warrant for making use of it in ways that are, for the possessor, possible and desirable. A person need not justify the possession of talents, despite the fact that one cannot be said to deserve them, because they are already one's own: the prima facie right to use and control talents is fixed by natural fact" $(1979,138)$.

${ }^{52}$ In this way, when we get to the bottom of desert, it turns out to presuppose a rudimentary conception of entitlement, or at least possession. We must have a sense of when a talent is mine and not Wilt's.
} 
Partly because giving credit is not essentially a zero-sum game, desert is not essentially a comparative notion. In particular, the models of desert developed here make room not for honoring those with advantages as compared to those without, but for honoring people who do what they can to be deserving of their advantages. These elements of a larger theory of justice ask whether a person has supplied the requisite desert makers, not whether the person has done more than someone else has. There are cases like the following:

(a) Wilt Chamberlain has $\mathrm{X}$ and you have $\mathrm{Y}$,

(b) Wilt did something to deserve $\mathrm{X}$ while you did something to deserve $\mathrm{Y}$,

(c) $\mathrm{X}$ is more than $\mathrm{Y}$, and yet (so far as desert is concerned),

(d) there is nothing wrong with $\mathrm{X}$ being more than $\mathrm{Y}$, despite the fact that Wilt does not deserve "more than you" under that description.

In other words, the question about Wilt is not whether Wilt did something to deserve more than you, but whether Wilt did something to deserve what he has. Perhaps there was never a time when an impartial judge, weighing your performance against Wilt's, had reason to conclude that Wilt's prize should be larger than yours. All that happened is that Wilt did justice to his opportunity and you did justice to yours. Should we focus on the relation, or imagine there is one, between you and Wilt? Or should we focus on a pair of relations, one between what Wilt did and what Wilt has, and another between what you did and what you have? Perhaps neither focus captures the whole truth about justice, but the second focus (that is, on the pair of relations) is a focus on desert, where the first is a focus on something else, something more comparative, such as equality.

A central distributor, intending to distribute according to desert, would need to judge relative deserts and then distribute accordingly. Without a central distributor, the situation is different. If Wilt worked hard for his salary of X, while you worked hard for your salary of $\mathrm{Y}$, there is something fitting in Wilt getting $\mathrm{X}$ and you getting $\mathrm{Y}$. You each supplied desert-making inputs connecting you to your respective salaries. It might be impossible for a central distributor to justify judging that Wilt deserves so much more than you, but by hypothesis there was no such judgment.

Needless to say, Wilt deserves no credit for the economic system that attaches a given salary to his performance. On the other hand, he does not need to deserve credit for the system. He claims credit only for his performance. If it is Wilt rather than you who deserves credit for Wilt's performance, then it is Wilt rather than you who has a presumptive claim to the salary that the system (or more accurately, Wilt's employer) attaches to Wilt's performance.

You may doubt Wilt's profession should be paid so much more than yours, not because you think people in top professions are undeserving, but because you think there is a presumption against that much inequality. ${ }^{53}$ You may think

\footnotetext{
${ }^{53}$ Olsaretti (2004, 166-68) says theories of desert cannot easily justify inequality. She is right, not because theories of desert fail in their attempt to justify inequality, but
}

no amount of desert could be enough to overturn that presumption. You may be right. It would have to be argued within the context of a theory of equality, which reminds us that, as just noted, there is more to justice than desert, and more to desert than deserving a chance.

Our reasons to respect desert as normally understood also are reasons to respect desert's limits as normally understood. In particular, there are limits to what a society can do, and limits to what society can expect its citizens to do, to ensure that people get what they deserve. Thus, even something as fundamental as the principle that people should get what they deserve has limits.

A just system works to minimize the extent to which people's entitlements fly in the face of what they deserve, but not at a cost of compromising people's ability to form stable expectations regarding their entitlements, and thus to get on with their lives in peaceful and productive ways. The point goes both ways, though, for desert in turn corrects the caprices of rightful entitlements, and that, too, is a good thing. For example, a proprietor may know her employee is entitled to a certain wage while also seeing that the employee is exceptionally productive and (in both promissory and compensatory senses) deserves a raise. If she cares enough about desert, she restructures her holdings (her payroll) accordingly, benefiting not only the employee but probably her company and her customers as well.

Think of the contrast this way: principles of entitlement acknowledge our status as separate agents. Principles of desert acknowledge our status as active agents.

A society cannot work without a "rule of law" system that secures people's savings and earnings, thereby enabling people to plan their lives. ${ }^{54}$ Neither can a rule of law function properly in the absence of an ethos that deeply respects what people can do to be deserving. ${ }^{55}$ Part of our job as moral agents is to do justice to opportunities embedded in our entitlements. It is in meeting that challenge that we make entitlement systems work.

\section{WORKS CITED}

Aristotle. (1962). Politics. Trans. T. A. Sinclair. London: Penguin.

Beitz, Charles. (1979). Political Theory and International Relations. Princeton, N.J.: Princeton University Press.

Brock, Gillian. (1999). Just Deserts and Needs. Southern Journal of Philosophy, 37 (2), 165-88.

because justifying inequality per se does not fall within their purview. Principles of equality may presuppose that inequality needs justifying, but principles of desert do not.

${ }^{54}$ Waldron (1989).

${ }^{55}$ What determines whether a given salary is a fitting response to desert-making inputs we supply? In the abstract, a theory of desert cannot say. Salaries are artifacts of systems of entitlement, and systems of entitlement are not pure responses to facts about what workers deserve. They also respond to notions of reciprocity, equality, and need, and to all kinds of factors (supply and demand) not directly related to matters of justice. Thus, the going rate for a type of work will not be determined by what a particular worker deserves, although whether a worker deserves to be paid the going rate will depend on whether she does something (supplies the expected desert-making inputs) to deserve it.

Some notions of desert are defensible by virtue of encouraging us to respect mutually advantageous systems of entitlement. Some notions of entitlement are defensible by virtue of empowering us to do something to deserve such opportunities as come our way. Which notion is more foundational? Out of context, there is no truth of the matter. In the context of aiming to justify a notion of desert, we must treat something else as foundational, if only for argument's sake. Likewise with entitlement. What we aim to justify defines the context and determines what can and what cannot be treated as foundational. 
Feinberg, Joel. (1970). Doing and Deserving. Princeton, N.J.: Princeton University Press.

Feldman, Fred. (1995). Desert: Reconsideration of Some Received Wisdom. Mind, 104 (1), 63-77.

Gauthier, David. (1986). Morals by Agreement. Oxford: Oxford University Press.

Hayek, F. A. (1960). The Constitution of Liberty. Chicago: University of Chicago Press.

Holmgren, Margaret. (1986). Justifying Desert Claims: Desert and Opportunity. Journal of Value Inquiry, 20 (3), 265-78.

Hugo, Victor. (1888). Les Misérables. Paris: Hetzel.

Kleinig, John. (1971). The Concept of Desert. American Philosophical Quarterly, 8 (1), 71-78.

Miller, David. (1976). Social Justice. Oxford: Oxford University Press. (1999). Principles of Social Justice. Cambridge, Mass.: Harvard University Press.

Miller, Fred D. (2001). Sovereignty and Political Rights. In Aristoteles Politik, ed. Otfried Höffe, 107-19. Berlin: Akademie Verlag.

Miller, Richard W. (1992). Justice as Social Freedom. In On the Track of Reason: Essays in Honor of Kai Nielsen, ed. Kai Nielsen, Roger Beehler, David Copp, and Bela Szabados, 37-55. Boulder, Colo.: Westview.

Moore, G. E. (1903). Principia Ethica. Cambridge: Cambridge University Press.
Morris, Christopher W. (1991). Punishment and Loss of Moral Standing. Canadian Journal of Philosophy, 21 (1), 53-79.

Narveson, Jan. (1995). Deserving Profits. In Profits and Morality, ed. Robin Cowan and Mario Rizzo, 48-97. Chicago: University of Chicago Press.

Olsaretti, Serena. (2004). Liberty, Desert, and the Market. Cambridge: Cambridge University Press.

Rachels, James. (1997). What People Deserve. In Can Ethics Provide Answers? 175-97. Lanham, Maryland: Rowman and Littlefield.

Rakowski, Eric. (1991). Equal Justice. Oxford: Oxford University Press.

Rawls, John. (1971). A Theory of Justice . Cambridge, Mass.: Belknap Press.

Scheffler, Samuel. (1992). Responsibility, Reactive Attitudes, and Liberalism in Philosophy and Politics. Philosophy and Public Affairs, 21 (3), 299-323.

Sher, George. (1987). Desert. Princeton, N.J.: Princeton University Press.

Waldron, Jeremy. (1989), The Rule of Law in Contemporary Liberal Theory. Ratio Juris, 2 (1), 79-96. (1995). The Wisdom of the Multitude: Some Reflections on Book 3, Chapter 11 of Aristotle's Politics. Political Theory, 23, 563-84.

Walzer, Michael. (1983). Spheres of Justice. New York: Basic Books.

Zaitchik, Alan. (1977), On Deserving to Deserve. Philosophy and Public Affairs, 6 (3), 370-88.

This is an open access article licensed under the terms of the Creative Commons Attribution Non-Commercial License (http://creativecommons.org/licenses/by-nc/3.0/) which permits unrestricted, non-commercial use, distribution and reproduction in any medium, provided the work is properly cited. 